\title{
Loss in macronutrient pools in bilberry and lingonberry in mesic Scots pine forests after Northern red oak introduction
}

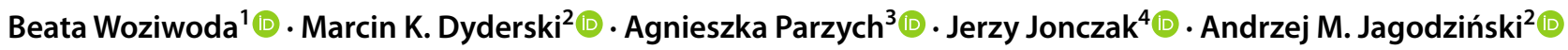

Received: 8 March 2021 / Revised: 24 August 2021 / Accepted: 8 September 2021 / Published online: 28 September 2021

(c) The Author(s) 2021

\begin{abstract}
Forest transformation from coniferous monocultures to mixed stands is being promoted worldwide, including the introduction of fast-growing broadleaved tree species within native stands. Here, we studied how enrichment of temperate European Scots pine (Pinus sylvestris) forest by North-American northern red oak Quercus rubra impacted macronutrient concentrations in two long-lived and dominant components of the forest understory: bilberry Vaccinium myrtillus and lingonberry V. vitisidaea. Study sites were located in forest complexes (central Poland) which occupy continuously reforested lands (hereafter ancient forests) as well as post-agricultural lands (recent forests), all suitable for mesic pine forests. Samples of bilberry and lingonberry leaves, stems, and fruits were collected in pine stands and in adjacent Scots pine-red oak stands, in both ancient and recent forests. Concentrations of macronutrients (C, N, P, K, Ca, S, and Mg) in aboveground biomass components were analysed using standardized chemical procedures. The study revealed intra- and interspecific (bilberry vs. lingonberry) differences in concentrations of all nutrients in leaves, stems, and fruits, except for invariable $\mathrm{C}$ concentrations. Macronutrient accumulations in plants were decreased by land-use discontinuity and favoured by enrichment of tree stands by $Q$. rubra. The estimated macronutrient pools were much higher for $V$. myrtillus than $V$. vitis-idaea in all forest types studied. They were lower in forests enriched with $Q$. rubra, both ancient (up to $25.5 \%$ for bilberry and $99.9 \%$ for lingonberry) and recent (46.9\% and $99.9 \%$, respectively), as well as in recent pine forest (46.6\% and $81.1 \%$, respectively) than in ancient pine forest. Higher $\mathrm{K}$ and S pools (39.3\% and 6.5\%, respectively) noted for bilberry in an ancient forest with $Q$. rubra were exceptions.
\end{abstract}

Communicated by Agustín Merino.

Beata Woziwoda

beata.woziwoda@biol.uni.lodz.pl

Marcin K. Dyderski

mdyderski@man.poznan.pl

Agnieszka Parzych

agnieszka.parzych@apsl.edu.pl

Jerzy Jonczak

jerzy_jonczak@sggw.edu.pl

Andrzej M. Jagodziński

amj@man.poznan.pl

1 Department of Geobotany and Plant Ecology, Faculty of Biology and Environmental Protection, University of Lodz, Banacha 12/16, 90-237 Łódź, Poland

2 Institute of Dendrology, Polish Academy of Sciences, Parkowa 5, 62-035 Kórnik, Poland

3 Department of Environmental Chemistry, Pomeranian University in Słupsk, Arciszewskiego 22b, 76-200 Słupsk, Poland

4 Department of Soil Science, Warsaw University of Life Sciences-SGGW, Nowoursynowska 159, 02-776 Warsaw, Poland 
Despite more effective accumulations of elements at the species level, macronutrient pools of Vaccinium myrtillus and $V$. vitis-idaea decreased significantly in the presence of introduced $Q$. rubra due to negative impacts of this broadleaved tree on bilberry and lingonberry cover and biomass. Therefore, the limitation of alien $Q$. rubra planting in sites of mesic pine forest with the abundant occurrence of $V$. myrtillus and/or V. vitis-idaea is recommended.

\section{Graphic abstract}
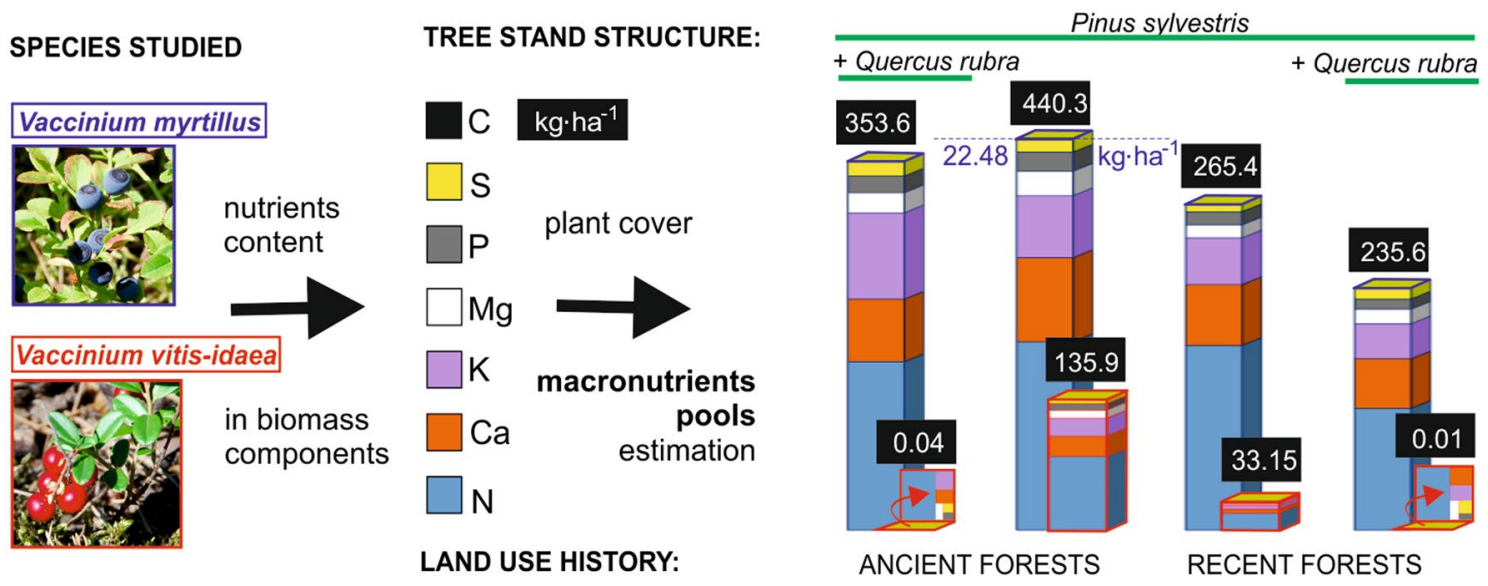

Keyword Coniferous forest transformation - Quercus rubra introduction · Carbon sequestration · Nutrient pools · Vaccinium myrtillus $\cdot$ Vaccinium vitis-idaea

\section{Background}

Vaccinium myrtillus L., known as bilberry (Nestby et al. 2011), and V. vitis-idaea L., known as lingonberry or cowberry (Luby et al. 1991), are common and dominant components of understory layers in temperate and boreal forests (Timoshok 2000; Turtiainen et al. 2013; Leuschner and Ellenberg 2017a). These long-lived ericaceous dwarf-shrubs play an important role in forest ecosystem functioning and yield valuable non-wood forest products (Woziwoda et al. 2019a, 2021, and references therein). By affecting the restoration of tree seedlings (Maubon et al. 1995; Jäderlund et al. 1996), they constitute one of the major drivers of vegetation dynamics (Nilsson and Wardle 2005; Kolari et al. 2006). Vaccinium myrtillus and V. vitis-idaea successfully colonize coniferous monocultures, including Scots pine (Pinus sylvestris L.) stands commonly planted on post-agricultural soils in Europe (Matuszkiewicz et al. 2013; Woziwoda et al. 2014b). Both species can co-occur at the same sites; however, they differ in adaptation to the environment which is reflected mainly in their leaf longevity: V. myrtillus is deciduous, and it sheds leaves every autumn, while evergreen $V$. vitis-idaea sheds 2-4-year-old leaves irregularly (Ritchie 1955, 1956). As $V$. myrtillus and $V$. vitis-idaea achieve high cover and biomass, they play an important role in ecosystem productivity and a regulating role in nutrient fluxes (Eeva et al. 2018; Grelet et al. 2001). The concentrations of elements in bilberry and lingonberry leaves, stems, fruits, and rhizomes, however, are modified by site conditions (e.g. Fernández-Calvo and Obeso 2004; Zvereva and Kozlov 2005; Jens et al. 2015; Mikulic-Petkovsek et al. 2015; Parzych 2016). Uptake of specific nutrients and accumulation in plants depends on their availability in soils and is modified by the co-occurrence of other nutrients (Barker and Pilbeam 2007; Marschner 2012). Concentrations of elements in plant leaves, stems, and fruits are naturally different, as specific biomass components are composed of different tissues and different biochemical processes occur within them. Furthermore, nutrient concentrations in specific organs change seasonally (Havas and Kubin 1983; Bujor et al. 2018). To avoid nutrient loss with litter, bilberry and lingonberry translocate elements from leaves to stems and rhizomes, and then, while conditions are favourable for growth-re-translocate them to developing tissues (Grelet et al. 2001). The most intensive bioaccumulation of nutrients in aboveground shoots occurs in the full vegetative season, during fruit ripening (Lahdesmaki et al. 1990). This is also a time for collection of bilberry and lingonberry fruits and leaves (a non-wood forest products, NWFP), both for domestic as well as industrial use (e.g. Turtiainen and Nuutinen 2012; Kilpeläinen et al. 2018).

Current studies on the effects of the North-American northern red oak Quercus rubra L. introduction to native 
European forests revealed strong negative impacts on both V. myrtillus (Woziwoda et al. 2019a) and V. vitis-idaea (Woziwoda et al. 2021). We found that the cover and aboveground biomass of bilberry and lingonberry were significantly lower in mixed Scots pine-northern red oak forests than in Scots pine monocultures. Quercus rubra suppressed the abundance of understory plants (Woziwoda et al. 2014a; Dyderski and Jagodziński 2021), mainly due to its significant effects on-site conditions, i.e. on light transmittance (Dyderski and Jagodziński 2019) and soil physicochemical parameters (Reich et al. 2005; Nicolini and Topp 2005; Bonifacio et al. 2015; Stanek et al. 2020). The continuity of forest land use also impacted bilberry and lingonberry cover and biomass, and differences in their abundances were noted in reforested lands (classified as ancient forests sensu Peterken 1974) versus afforested post-agricultural lands (recent forest). However, it is still unknown how these changes affected the chemical composition of plants. The recognition of nutrient concentrations in floral components of the forest understory is of crucial importance for the assessment of the effects of man-made changes in tree stand composition and land-use form, and consequently, for proper forest management. This issue requires urgent clarification also because commercially important $Q$. rubra has been commonly underplanted in European coniferous forests (Woziwoda et al. 2014c; Nicolescu et al. 2020), and at present it spreads spontaneously in an uncontrolled way (e.g. Woziwoda et al. 2018, 2019b; Chmura 2020; Dyderski and Jagodziński 2020a; Dyderski et al. 2020). The recognition of macronutrient concentrations in $V$. myrtillus and $V$. vitis-idaea at the peak of the plant's growing season can be also useful for bilberry and lingonberry pickers, dwellers, and consumers.

In this study, we examined concentrations of macronutrients (C, N, P, K, Ca, S, and $\mathrm{Mg}$ ) in aboveground shoots of $V$. myrtillus and V. vitis-idaea in mesic Scots pine forests and Scots pine-northern red oak forests with different land-use histories. The question was, are there any general patterns in the impacts of former land-use changes and alien tree occurrence on bilberry and lingonberry chemical composition, and especially, does $Q$. rubra impact species-specific bioaccumulation of macronutrients in these long-lived dwarf shrubs? If yes, how are they related to environmental factors, e.g. to light conditions? And finally, how have the bilberry and lingonberry nutrient pools changed in the forest understories of different forest types studied?

\section{Material and methods}

The plant material-lingonberry and bilberry shoots, was collected in four forest types: ancient pine forest (AFP, treated as reference), recent pine forest (RFP), ancient pine forest with introduced Quercus rubra (AFQ), and recent pine forest with introduced Quercus rubra (RFQ).

\section{Study area}

The study site was located in central Poland, in two forest complexes: Aleksandrówek (ancient forest; $51.8599^{\circ} \mathrm{N}$, $18.9912^{\circ} \mathrm{E}$ ) and Małyń-Jerwonice (recent forest planted about one hundred years ago on former agricultural lands excluded from cultivation due to low fertility of soils; $51.7803^{\circ} \mathrm{N}, 19.0455^{\circ} \mathrm{E}$, ca $10 \mathrm{~km}$ from the ancient forest). The mean annual temperature of this area is $8.4^{\circ} \mathrm{C}$, and the mean annual precipitation is $605 \mathrm{~mm}$ (Kożuchowski 2011). Soils of the study sites represent Haplic Podzols in the ancient forest, and Albic Brunic Arenosols in the recent forest, according to the World Reference Base for Soil Resources classification system (WRB 2015). The soils developed from Quaternary fluvioglacial sands. They are characterized by medium moisture content (despite coarse granulation), strongly acidic $\mathrm{pH}(4-5)$, and a low abundance of nutrients (SHS 2003). Both forest complexes are commercial (timber wood production is the main management goal), but also public, with open access for recreational activity including free berry picking. The ancient pine forest (AFP) is an 86-year-old $P$. sylvestris monoculture, and it is adjacent to a pine forest with $Q$. rubra (AFQ) intentionally planted under a pine canopy a half-century ago. Both ancient forest types studied occupy one forest division with a total area of 12.8 ha, one-third of which has $Q$. rubra. The recent pine forest (RFP) is a 69-year-old monoculture of $P$. sylvestris (2.9 ha), adjacent to a 100 -year-old stand of P. sylvestris with 35-year-old $Q$. rubra (RFQ), also intentionally planted on the area of 10.95 ha. At present, numerous Q. rubra trees form a dense and continuous canopy below crowns of the Scots pine trees, both in ancient and recent forest (Table 1, Fig. 1).

Juveniles of $Q$. rubra and other deciduous tree species (rowan Sorbus aucuparia, alder buckthorn Frangula alnus, silver birch Betula pendula, pedunculate oak $Q$. robur) occur in the shrub layer (b) of the studied forests. The understory vascular plant layer (c) is dominated by bilberry and/or lingonberry dwarf shrubs, and in some places-by grasses: Deschampsia flexuosa and Festuca ovina. The moss layer (d) covers almost all the ground in both pine forests (AFP and RFP), while it is sparse in forests with Q. rubra (AFQ and RFQ) (Fig. 1).

\section{Light environment estimation}

To characterize light conditions in the understory layer, we conducted a vegetation survey of 15 randomly sampled plots $\left(100 \mathrm{~m}^{2}\right)$ per forest type, recording all vascular plant and bryophyte species (see details in Woziwoda 
Table 1 Tree stand density, mean trunk circumference at $1.3 \mathrm{~m}$ height $( \pm$ standard deviation) and growing stock of the forests studied: ancient pine forest (AFP, treated as reference), ancient pine forest with introduced Quercus rubra (AFQ), recent pine forest (RFP) and recent pine forest with introduced Q. rubra (RFQ)

\begin{tabular}{|c|c|c|c|c|}
\hline & AFP & AFQ & RFP & RFQ \\
\hline \multicolumn{5}{|l|}{ Tree stand density } \\
\hline \multicolumn{5}{|l|}{ Pinus sylvestris (a1) } \\
\hline Ind. ha ${ }^{-1}$ & $693 \pm 118$ & $480 \pm 168$ & $847 \pm 222$ & $613 \pm 141$ \\
\hline Trunk circum. $(\mathrm{cm})$ & $72.8 \pm 13.6$ & $96.5 \pm 17.5$ & $78.7 \pm 18.0$ & $83.4 \pm 15.2$ \\
\hline \multicolumn{5}{|l|}{ Quercus rubra (a2) } \\
\hline Ind. ha ${ }^{-1}$ & - & $940 \pm 555$ & - & $640 \pm 558$ \\
\hline Trunk circum. $(\mathrm{cm})$ & - & $24.5 \pm 15.2$ & - & $29.8 \pm 8.3$ \\
\hline \multicolumn{5}{|l|}{ Quercus rubra (b) } \\
\hline Ind. $\mathrm{ha}^{-1}$ & + & $500 \pm 440$ & + & $250 \pm 92$ \\
\hline Trunk circum. $(\mathrm{cm})$ & - & $10.9 \pm 3.9$ & - & $12.7 \pm 5.1$ \\
\hline${ }^{*}$ Growing stock $\left(\mathrm{m}^{3} \mathrm{ha}^{-1}\right)$ & 263 & 263 & 366 & 336 \\
\hline
\end{tabular}

Data estimates are from field inventories of this study except for growing stock (asterisk), which is from the Forest Data Bank (FDB 2018) (data published in Woziwoda et al. 2019a). Tree stand labelling: a1—upper tree canopy layer, a2 - lower tree canopy layer, b—shrub layer, following Braun-Blanquet (1964)
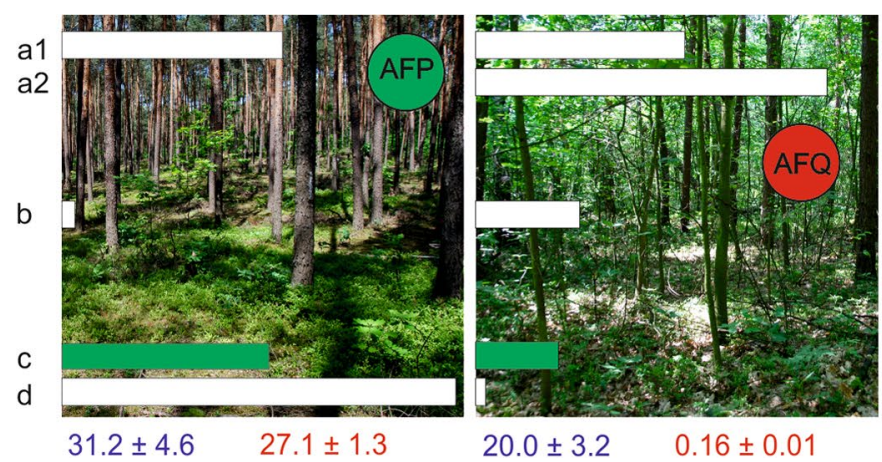

$20.0 \pm 3.2$

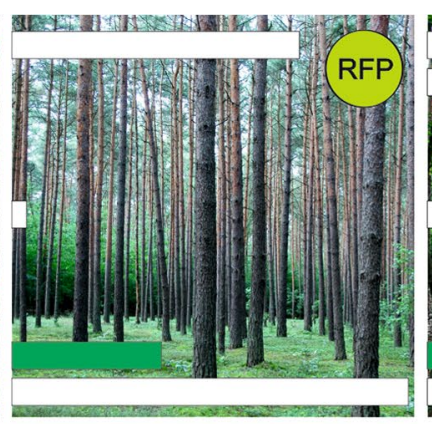

$21.1 \pm 3.5 \quad 13.7 \pm 0.8$

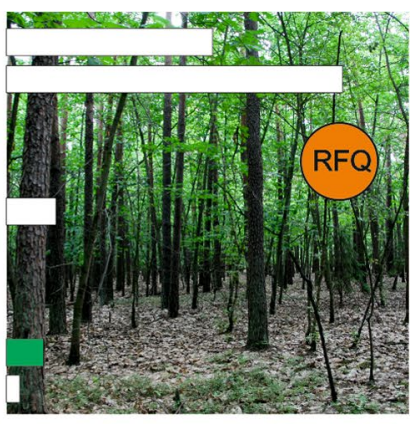

$9.0 \pm 3.5 \quad 0.03 \pm 0.03$
Fig. 1 Forest types studied: ancient pine forest (AFP), ancient pine forest with introduced Quercus rubra (AFQ), recent pine forest (RFP), recent pine forest with introduced $Q$. rubra (RFQ), and their structure described by mean cover of forest layers (the picture width $=100 \%$ cover of the layer): a1-upper tree canopy layer, a2-lower tree canopy layer, b-shrub layer, c-herb layer

et al. 2021). We recorded the cover of each species using the Braun-Blanquet (1964) scale. To describe the light conditions, we used two indicators widely used in plant community ecology: Ellenberg's light ecological indicator value (EIV.L) from Ellenberg and Leuschner (2010) and specific leaf area (SLA, expressed in $\mathrm{cm}^{2} \mathrm{~g}^{-1}$ ) obtained from the LEDA database (Kleyer et al. 2008) and PaźDyderska et al. (2020). For each plot, we calculated community-weighted mean values of EIV.L and SLA, i.e. mean weighted by species cover. For EIV.L, we used data for vascular plants and bryophytes and vascular plants only, while SLA reflected only the vascular plant community. We decided to analyse EIV.L for both vascular plants and bryophytes, as the latter dominate the understory in AFP and RFP and are also responsive to light availability (Dyderski and Jagodziński 2020b). We used one-way ANOVA followed by Tukey's posteriori test to assess the (with ericaceous dwarf shrubs), and d-moss layer; and the cover (mean \pm standard error) of bilberry Vaccinium myrtillus (in blue) and lingonberry $V$. vitis-idaea (in red) noted for each forest type. Data were estimated from our field phytosociological studies made following Braun-Blanquet (1964)

differences in EIV.L and SLA community-weighted mean values among forest types studied.

\section{Samples collection}

Vaccinium myrtillus and V. vitis-idaea aboveground shoots (ramets) were collected in June-July (for bilberry) and August-September (for lingonberry) 2017, in 400 research plots in total $(50$ research plots, each $50 \times 50 \mathrm{~cm}$ in area, set up in the Scots pine forests with and without $Q$. rubra, in each of the two localities, and located randomly in clumps of $V$. myrtillus and V. vitisidaea; for more information see Woziwoda et al. 2019a, 2021). Bilberry and lingonberry sampling in different months was necessary due to phenological differences in the development of their shoots and berries-in the study area, bilberry fruits one month earlier than lingonberry, 
and shoots were collected at the peak of the species-specific fruiting season. Sampling time variation allowed us to avoid mistakes connected with seasonal changes in nutrient accumulation in specific components (i.e. leaves, stems, and fruits) caused by translocation of elements within the plant.

Ramets (ten in each plot, randomly chosen) of both species studied, separated into stem, leaves, and fruits, dried and packed in marked closed polyethylene bags (Woziwoda et al. 2019a, 2021), were used for studies. For chemical analysis, ten samples of lingonberry and bilberry leaves and stems, each at around $10 \mathrm{~g}$ of mass, were separated from dried material gathered for each of the four variants studied (160 samples in total). Ten-gramsamples contained dried plant material composed from samples deposited in subsequently numbered bags. In the same way, 40 ten-gram-samples of bilberries (ten samples for each of four variants) and 20 ten-gram-samples of lingonberries (ten samples for each of two pine forest variants; in forests with $Q$. rubra lingonberry did not produce fruits, Woziwoda et al. 2021) were composited from samples of dried berries. Samples of leaves, stems, and fruits (biomass components) - 220 in total, were sent to the laboratory for chemical analysis.

\section{Laboratory analyses}

The plant material was homogenized in a laboratory grinder (IKA A11, Germany). Until the time of analyses, the samples had been kept in leak-proof, closed polyethylene bags. To determine the total phosphorus and metallic elements, the plant samples $(0.5 \mathrm{~g})$ were digested in a solution of $65 \% \mathrm{HNO}_{3}$ acid and $30 \% \mathrm{H}_{2} \mathrm{O}_{2}(1: 1 \mathrm{v} / \mathrm{v})$ in a closed system. Then, the samples were supplemented with deionized water (Hydrolab, HLP 10, Poland) to a volume of $50 \mathrm{ml}$. The concentration of $\mathrm{P}$ was determined by spectrophotometry with a molybdenum-blue method (5001 Hitachi, Japan). The concentrations of $\mathrm{Mg}$ and $\mathrm{Ca}$ were determined by atomic absorption spectrometry, and $\mathrm{K}$ was determined by atomic emission spectrometry (AAS 2100, PerkinElmer, USA). Element concentrations were expressed on a dry weight basis. The wavelengths at which the various metals were detected were as follows: $\mathrm{K} 766.5 \mathrm{~nm}, \mathrm{Mg} 285.2 \mathrm{~nm}$, and Ca $422.7 \mathrm{~nm}$. The tests were carried out following the original standards (Merck KGaA, $1 \mathrm{~g} / 1000 \mathrm{~mL}$ ). All analyses were carried out in three replicates, and the samples were represented by average values (the variance of the replicates was checked, and outliers were skipped). Total concentrations of organic $\mathrm{C}, \mathrm{N}$, and $\mathrm{S}$ were determined by dry combustion using the MacroCube CHNS analyser (Elementar, Germany).

\section{Quality assurance/quality control (QA/QC)}

The QA/QC of the analytical procedures was carried out by analysing the standard certified reference material of plants (CRM 060), adopting the same procedures as for the analysed samples. The results of the experimental measurements agreed with the recommended reference value material. Analysis of most of the elements is accurate within a $3 \%$ analytical error. Recoveries were calculated as a ratio of the determined value to the certified one and were within the confidence intervals of the certified values. Recoveries were as follows: $99 \pm 2 \%(\mathrm{P}), 98 \pm 3 \%(\mathrm{~K}), 98 \pm 2 \%(\mathrm{Mg})$, $97 \pm 3 \%(\mathrm{Ca})$. Birch leaf certified reference material (B2166, Elemental Microanalysis) was used to ensure the quality of $\mathrm{C}, \mathrm{N}$, and $\mathrm{S}$ analyses.

\section{Data analyses}

All analyses were conducted using R software (R Core Team 2019). We compared the chemical composition of studied plants using redundancy analysis (RDA) - a constrained version of principal components analysis. In RDA, we used scaled (i.e. subtracting the mean and dividing by SD) macronutrient concentration and $\mathrm{C}: \mathrm{N}$ ratio. As constraints, we assumed species, forest variant, and biomass component. We conducted RDA using the vegan package (Oksanen et al. 2018). Before analyses, we ensured that variables are not intercorrelated using variance inflation factors. Then, we compared the full model with the null model using Akaike's Information Criterion (AIC) and we tried to reduce model AIC by reducing the number of variables. We also used variance partitioning to show how much variability is explained by a particular variable.

We calculated the mean concentrations of studied macronutrients and mean nutrient masses in plant tissues for each treatment. To calculate nutrient pools, we used data from previous studies on biomass allocation (Woziwoda et al. 2019a, 2021). We used mean biomass allocation into stems, leaves, and fruits in each forest variant, mean ecosystem-level dry biomass, and mean nutrient concentrations to obtain a pool of each nutrient for bilberry. For lingonberry, we used mean biomasses of components, mean lingonberry cover, and mean nutrient concentrations to obtain nutrient pools. We referred to AFP as a reference, calculating differences connected with land-use change (ancient versus recent forest) and with $Q$. rubra (pine versus red oak). We calculated how SE of estimation is propagated following:

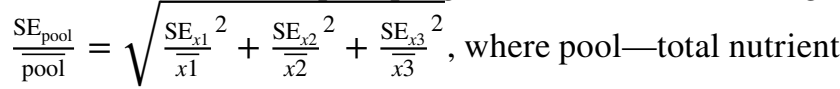
pool in the ecosystem (mass of a particular element in organs of the species studied), $\times 1-\times 3$-variables used in 
Table 2 Ranges, mean, and SE values of community-weighted mean Ellenberg's ecological indicator values of light requirements for both bryophytes and vascular plants (EIV.L) and vascular plants only (EIV.L vascular), and specific leaf area (SLA) of understory vegeta- tion ( $n=15$ per variant) in ancient pine forest (AFP), ancient pine forest with introduced Quercus rubra (AFQ), recent pine forest (RFP), recent pine forest with introduced $Q$. rubra (RFQ), assessed using one-way ANOVA

\begin{tabular}{|c|c|c|c|c|c|c|}
\hline Variable & Variant & $\min$ & mean & SE & $\max$ & Tukey test \\
\hline \multirow[t]{4}{*}{ SLA } & AFP & 119.62 & 168.96 & 8.00 & 221.42 & $\mathrm{C}$ \\
\hline & AFQ & 156.29 & 239.22 & 6.28 & 260.05 & A \\
\hline & RFP & 129.48 & 199.01 & 8.72 & 240.64 & $\mathrm{Bc}$ \\
\hline & RFQ & 145.88 & 206.11 & 11.66 & 257.34 & $\mathrm{Ab}$ \\
\hline \multirow[t]{4}{*}{ EIV.L } & AFP & 5.51 & 5.76 & 0.05 & 6.15 & A \\
\hline & AFQ & 4.89 & 5.08 & 0.04 & 5.50 & $\mathrm{C}$ \\
\hline & RFP & 5.63 & 5.78 & 0.03 & 6.00 & A \\
\hline & RFQ & 4.80 & 5.37 & 0.10 & 5.92 & B \\
\hline \multirow[t]{4}{*}{ EIV.L vascular } & AFP & 5.07 & 5.52 & 0.10 & 6.45 & A \\
\hline & AFQ & 4.76 & 5.16 & 0.08 & 6.25 & A \\
\hline & RFP & 5.07 & 5.29 & 0.07 & 6.02 & A \\
\hline & RFQ & 5.00 & 5.37 & 0.17 & 7.00 & A \\
\hline
\end{tabular}

Variants marked with the same letter did not differ statistically significantly $(p>0.05)$, according to Tukey's posteriori test

calculations, SE-standard error. We used SE instead of SD or variance due to uneven sample size, which affects error calculations. Then, to show nutrient pools in each treatment we summed nutrient pools in each biomass component, assuming additive error propagation. We assessed the impacts of land-use history and $Q$. rubra invasion using ANOVA. We quantified the influences of both factors and their interaction using the modEva::varPart() function (Barbosa et al. 2013). After ANOVA, we compared the significance of mean values by Tukey posteriori tests and we calculated marginal mean values of each treatment using the emmeans package (Lenth 2019). The same procedure was applied at the concentration and ecosystem level.

\section{Results}

\section{Difference in light conditions among forest types}

Regardless of the indirect light availability indicator used, ANOVA revealed significant differences among forest types analysed $\left(\mathrm{F}_{3,56}=33.72, p<0.0001\right.$ and $\mathrm{F}_{3,56}=10.05$, $p<0.0001$ for EIV.L and SLA, respectively). Considering only vascular plant species, the community-weighted mean of EIV.L did not differ statistically significantly $\left(\mathrm{F}_{3,56}=1.84\right.$, $p=0.151)$. AFP had the lowest SLA, indicating the highest light availability, as well as the highest value of EIV-L. RFP did not differ statistically significantly from AFP both in terms of EIV-L and SLA community-weighted means. Results indicate lower light availability in forests with $Q$. rubra (Table 2).

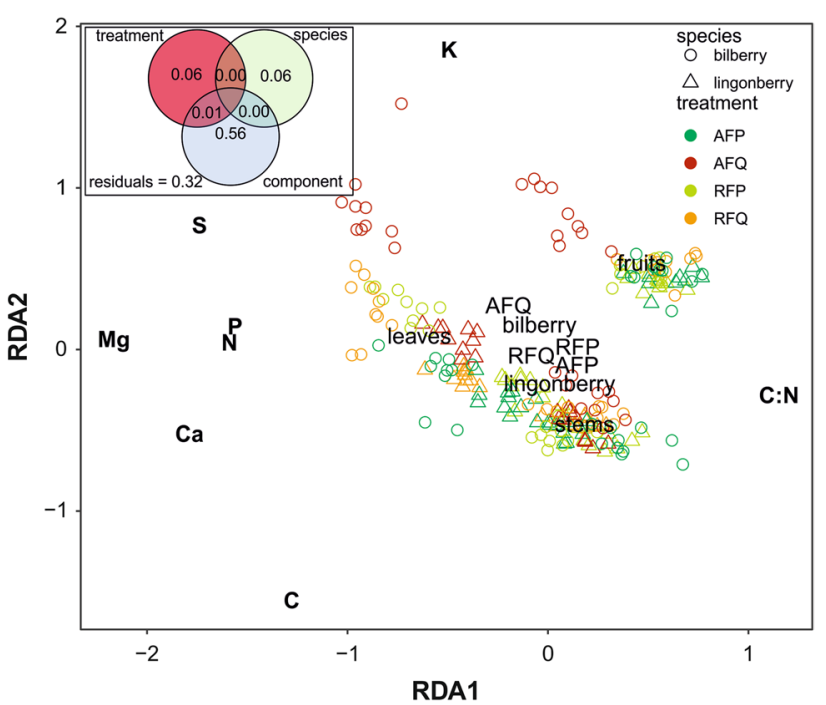

Fig. 2 Redundancy analysis (RDA) showing patterns of macronutrient composition within the studied samples. Points represent samples, bold labels-numeric variables, regular font labels-constraining factors. Upper-left subplot: Venn diagram representing variance partitioning among RDA constraints. RDA AIC $=214.44$, AIC of null model (without constraints) $=458.47$. Significance of constraints fitness: Table 3

Table 3 The fit of environmental traits to redundancy analysis (RDA) results evaluated using a PERMANOVA test (999 iterations)

\begin{tabular}{lrlll}
\hline Constraining variable & $d f$ & variance & $F$ & $\operatorname{Pr}(>F)$ \\
\hline Forest type & 3 & 0.650 & 18.560 & 0.001 \\
Species & 1 & 0.467 & 39.992 & 0.001 \\
Biomass component & 2 & 4.396 & 188.231 & 0.001 \\
Residuals & 213 & 2.487 & - & - \\
\hline
\end{tabular}




\section{Variability of macronutrient concentrations}

Analysis of macronutrient concentration patterns showed that the main driver of variability was the biomass component (leaves, stems, fruits), responsible for $56 \%$ of variability explained by the model (Fig. 2, Table 3). Species (lingonberry or bilberry) and forest type (AFP, AFQ, RFP, RFQ) each explained $6 \%$ of the variability. The ordination diagram revealed a clear distinction between fruits (upper right part of the plot) and other components, as well as between leaves and stems (between the labels of 'lingonberry' and 'stems'). All these factors significantly drove the chemical composition of berries. We found more samples from pine forests with $Q$. rubra at the left side of the ordination diagram, but no differences between ancient and recent forests.

\section{Macronutrient concentrations in biomass components: differentiation between species and among forest types}

For bilberry, we found higher concentrations of macronutrients in leaves than in stems and fruits (Fig. 3). Differences in $\mathrm{C}$ concentration among forest types were negligible. Higher leaf $\mathrm{N}$ and $\mathrm{K}$ concentrations, as well as lower $\mathrm{C}: \mathrm{N}$ ratios, were noted in $V$. myrtillus from the recent pine forest and both pine forests with $Q$. rubra than from ancient pine forest. The concentration of $P$ was the highest in leaves of bilberry from the recent pine forest and ancient pine forest with $Q$. rubra. In stems, we found the highest $\mathrm{N}$ and $\mathrm{Ca}$ concentrations in RFP, while stem $\mathrm{K}$ concentration was higher in AFQ than in the other three forest types. Concentrations of $\mathrm{N}, \mathrm{S}$, $\mathrm{K}$, and $\mathrm{Mg}$ in fruits were also higher in AFQ than in other forest types.

The presence of $Q$. rubra was the most important factor for most leaf nutrients studied, while stem nutrients were more affected by land-use history (Fig. 4). Q. rubra mostly affected $\mathrm{S}$ and $\mathrm{Mg}$ concentrations all biomass components of bilberry, as well as leaf $\mathrm{N}, \mathrm{K}$, and Ca concentrations, while land-use change mostly affected stem $\mathrm{N}, \mathrm{K}$, and $\mathrm{Ca}$ concentrations, as well as stem $\mathrm{C}: \mathrm{N}$ ratio.

For lingonberry, we found higher concentrations of macronutrients in leaves than stems, except $\mathrm{C}$, for which concentrations were aligned (Fig. 5). In pine forests with Q. rubra (AFQ and RFQ), we found higher $\mathrm{N}$ and $\mathrm{S}$ leaf concentrations, and lower $\mathrm{C}: \mathrm{N}$ ratio and $\mathrm{P}$ concentration (in AFQ only) than in pine forests. Leaf $\mathrm{K}$ concentration was higher in AFQ than in other forest types. We also found lower stem $\mathrm{N}$ concentrations in RFQ than in the other three forest types, as well as lower stem $\mathrm{K}$ concentration in recent than in ancient forests.

Leaf macronutrient concentrations were more affected by Q. rubra than by land-use change (Fig. 4), especially for N, $\mathrm{S}$, and $\mathrm{P}$ concentrations, and $\mathrm{C}: \mathrm{N}$ ratio. To a lesser degree, this factor also affected stem macronutrient concentrations ( $\mathrm{Mg}, \mathrm{Ca}, \mathrm{S}, \mathrm{P}$, and $\mathrm{N}$ ), as well as $\mathrm{C}: \mathrm{N}$ ratio. Stem $\mathrm{K}$ concentration, however, was mostly affected by land-use change. Vaccinium vitis-idaea did not produce berries in pine forests with $Q$. rubra, both ancient and recent (Woziwoda et al. 2021), so macronutrient concentrations in lingonberries were the most affected by this species ( $Q$. rubra limited allocation of elements in fruits to zero). Fruit macronutrient concentrations in both pine forests were more affected by land-use change than leaf and stem concentrations (Fig. 4).

\section{Nutrient pools in forest understory}

The estimated macronutrient pools were much higher for $V$. myrtillus than V. vitis-idaea in all forest types studied (Table 4). Land-use change and Q. rubra affected nutrient pools of lingonberry more (up to $99.9 \%$ ) than bilberry (up to $46.9 \%$; Table 4). Land-use change decreased (in comparison with AFP) the P pool in bilberry more than Q. rubra, but increased $\mathrm{K}$ and $\mathrm{S}$ pools, in comparison with ancient pine forest (39.3\% and 6.5\%, respectively). However, for bilberry, the highest nutrient pool decreases were found in the recent pine forest with $Q$. rubra, with the $\mathrm{C}$ and $\mathrm{P}$ pools most affected (46.5\% and $46.9 \%$ lower, respectively). For lingonberry, the extremely high decreases in nutrient pools (for all elements studied) were found in both forests with $Q$. rubra (Table 4). The lowest decreases (but still exceeding $70 \%$ ) were found in the recent pine forest, with the S and C pools least affected (73.2\% and $75.6 \%$ lower, respectively) and $\mathrm{Ca}$ and $\mathrm{Mg}$ pools most affected $(81.1 \%$ and $80.6 \%$ lower, respectively).

\section{Discussion}

In line with our expectations, the biomass components were the main drivers of the variability of nutrient concentrations. The low species-specific differences in macronutrient concentrations were also expected as both species studied are congeneric. However, species-specific differences occurred, as the species studied differ in life strategy (deciduous vs. evergreen), which is reflected in their chemical composition (Grelet et al. 2001; Barker and Bryson 2007). The most important differences in species-specific macronutrient concentrations revealed here were those indicating the different reactions of $V$. myrtillus and $V$. vitis-idaea to changes in light condition after deciduous tree introduction and past changes in land use (ancient $v s$. recent forests). Differences in macronutrient concentrations in plant species studied could also result from nutrient availability in soils or modifications of nutrient uptake due to the occurrence of other elements (Barker and Pilbeam 2007; Marschner 2012); further studies are needed. 
Fig. 3 Mean (+SE) concentrations of macronutrients and $\mathrm{C}: \mathrm{N}$ ratios in Vaccinium myrtillus growing in four forest types: AFP — ancient pine forest, $\mathrm{AFQ}$ - ancient pine forest with introduced $Q$. rubra, RFPrecent pine forest, RFQ-recent pine forest with introduced $Q$. rubra. Groups denoted by the same letters did not differ statistically significantly $(p<0.05)$ according to the Tukey posteriori tests. For models - see Appendix A

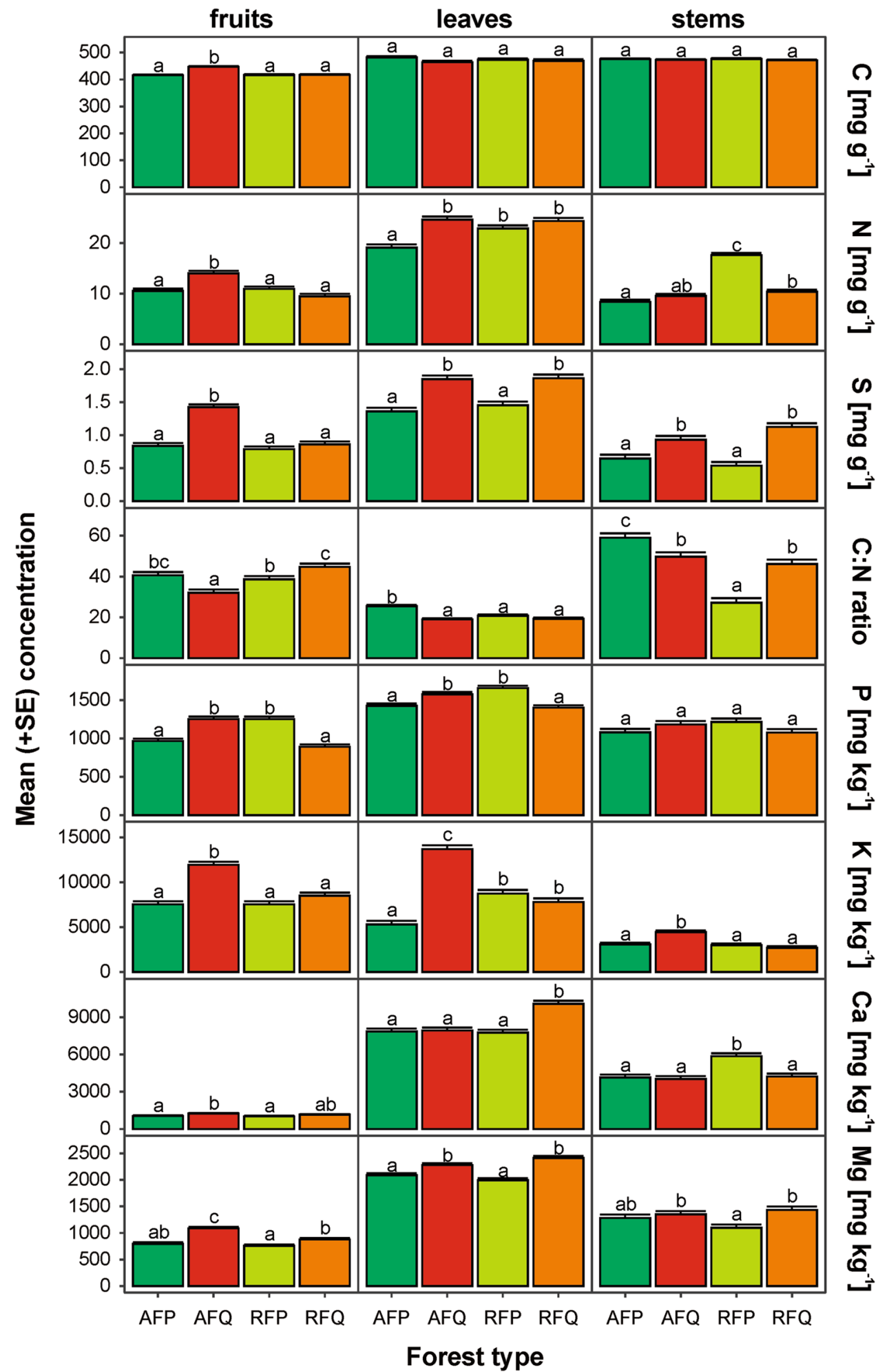

Vaccinium myrtillus and $V$. vitis-idaea shoots were mainly composed of carbon, and so its high concentration (nearly $50 \%$ of dry mass) was expected. No intra- and interspecific differences in $\mathrm{C}$ concentration were found in bilberry and lingonberry leaves, stems, or fruits, both within and between mesic pine forest types studied. However, results of this study combined with our earlier data (Woziwoda et al. 2019a, 2021) revealed the important roles of $V$. myrtillus and $V$. vitis-idaea in C sequestration and storage in the Scots pine forest ecosystems, consistent with data from other European 
Fig. 4 The proportion of variance explained by $Q$. rubra, land-use change (ancient-recent forest), and their interactions in models of macronutrient concentrations and C: $\mathrm{N}$ ratios in bilberry Vaccinium myrtillus and lingonberry $V$. vitis-idaea. For models-see Appendix A

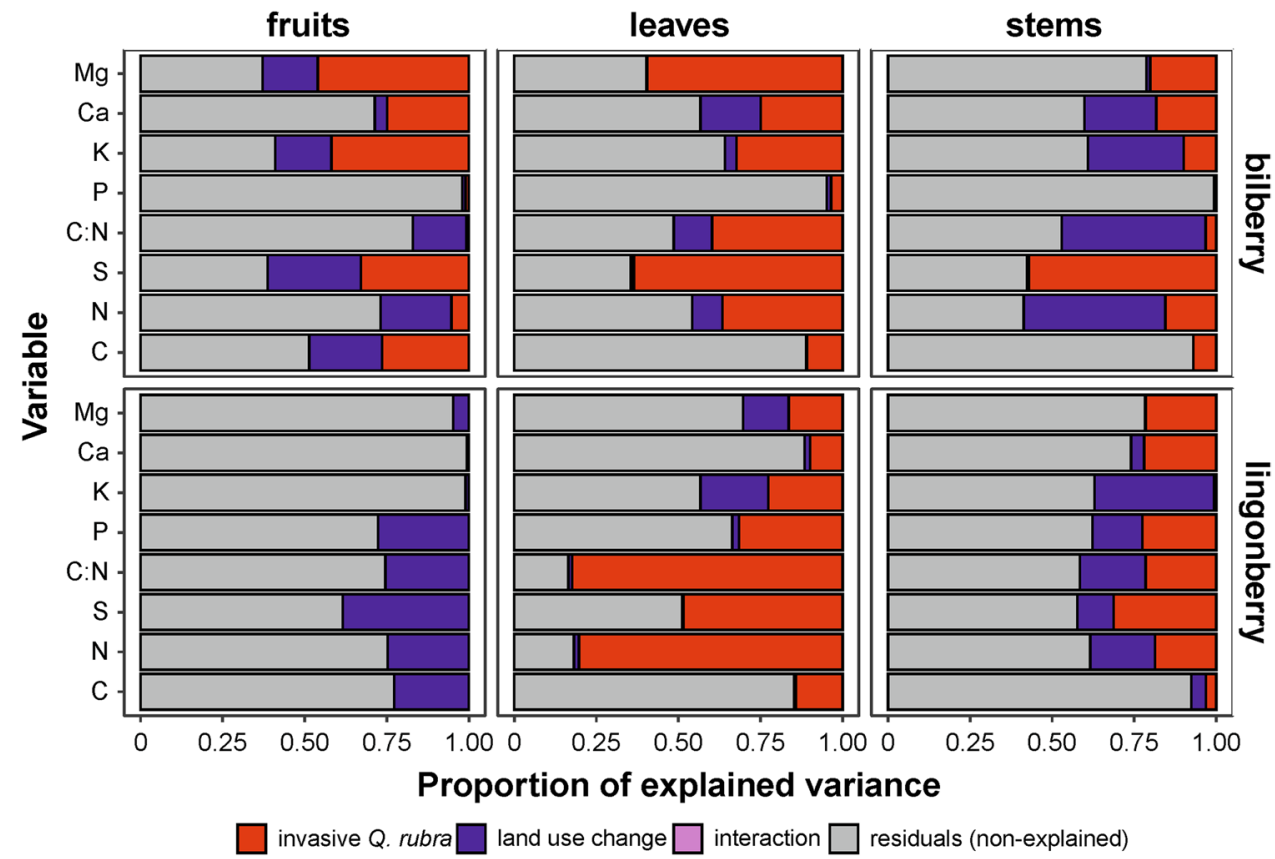

coniferous forests (Nilsson and Wardle 2005; Kolari et al. 2006; Rodriguez and Kouki 2015). As bilberry colonizes recent forests faster than lingonberry (Matuszkiewicz et al. 2013) and is more resistant to negative impacts of introduced alien oak (Woziwoda et al. 2014a, 2019a), it seemed to be more important for $\mathrm{C}$ storage. Indeed, the estimated $\mathrm{C}$ pool of aboveground shoots of $\mathrm{V}$. myrtillus was eight times higher in pine monoculture planted on post-agricultural soil, and multiple times higher in both recent and ancient forests with Q. rubra, than V. vitis-idaea C pools (Table 4). Moreover, in reference plots (ancient pine forest) the estimated C pool of V. myrtillus was also more than three times higher than the V. vitis-idaea $\mathrm{C}$ pool.

The different concentrations of the next major element - nitrogen, noted in leaves, stems, and fruits were also expected (Barker and Bryson 2007; Marschner 2012). However, we found that whole aboveground shoots of $V$. myrtillus in recent forest and $V$. vitis-idaea in the ancient and recent forests contained less $\mathrm{N}$ in stands with $Q$. rubra than in pure Scots pine stands. The highest $\mathrm{N}$ concentration in leaves in mixed stands was linked with lower exposure of plants to sunlight (see Table 2), and light conditions strongly affect the growth, performance, and chemical composition of bilberry and lingonberry plants (Sjönberg et al. after Atlegrim 1989; Messier et al. 1998; Frelich et al. 2003; Uleberg et al. 2012; Nestby et al. 2011, 2014b). Both species studied react to decreases in light availability by specific leaf area (SLA) increases (Paź-Dyderska et al. 2020), and SLA is positively correlated with $\mathrm{N}$ concentration (Wright et al. 2004; Díaz et al. 2016). Higher N concentration noted in bilberry than lingonberry leaves can also result from the tendency of $\mathrm{N}$ to concentrate in the most intensively growing points of the plant (Tegeder and Masclaux-Daubresse 2018), i.e. in deciduous bilberry leaves. $\mathrm{N}$ accumulated in plants is naturally re-used by them in growing tissues. However, within-plant $\mathrm{N}$ management varies depending on whether the plant is evergreen (lingonberry) or deciduous (bilberry) (Barker and Bryson 2007). Vaccinium myrtillus remobilizes $\mathrm{N}$ to intensively growing deciduous leaves and new shoots from previous year stems and roots, while $V$. vitis-idaea retranslocates $\mathrm{N}$ predominately from previous year evergreen leaves (Grelet et al. 2001). Moreover, N remobilization from older lingonberry leaves to new ones occurs slowly during the vegetative season, while remobilization of $\mathrm{N}$ from long-lived bilberry stems and roots to seasonal leaves occurs faster. All these facts resulted in higher $\mathrm{N}$ concentrations noted in lingonberry stems than leaves in both pine forests, while in mixed forests more $\mathrm{N}$ was noted in leaves, as leaves are bigger there (Paź-Dyderska et al. 2020) and grow more intensively. However, intraspecific SLA plasticity in V. vitis-idaea is low (Paź-Dyderska et al. 2020), and this evolutionary incapacity can be responsible for lingonberry decline after broadleaved tree planting (or their spontaneous encroachment) (Woziwoda et al. 2018) in the Scots pine stands. Admittedly, slow biomass turnover supports efficient internal N-cycling and favours $\mathrm{N}$ accumulation (Grelet et al. 2001); however, lingonberry shoots contained less $\mathrm{N}$ than bilberry shoots. Results of this study confirmed that $V$. myrtillus more effectively uptakes nutrients from the soil than V. vitis-idaea (Sjönberg et al. after Atlegrim 1989; Parzych 2016). The lower $\mathrm{N}$ concentrations in whole (aboveground) shoots found in mixed forests than in pine forests could also 
Fig. 5 Mean (+SE) concentrations of macronutrients and $\mathrm{C}: \mathrm{N}$ ratios in lingonberry Vaccinium vitis-idaea growing in four forest types: AFP-ancient pine forest, $\mathrm{AFQ}$ - ancient pine forest with introduced $Q$. rubra, RFP—recent pine forest, RFQ—recent pine forest with introduced $Q$. rubra. Groups denoted by the same letters did not differ statistically significantly $(p<0.05)$ according to the Tukey posteriori tests. For models-see Appendix A

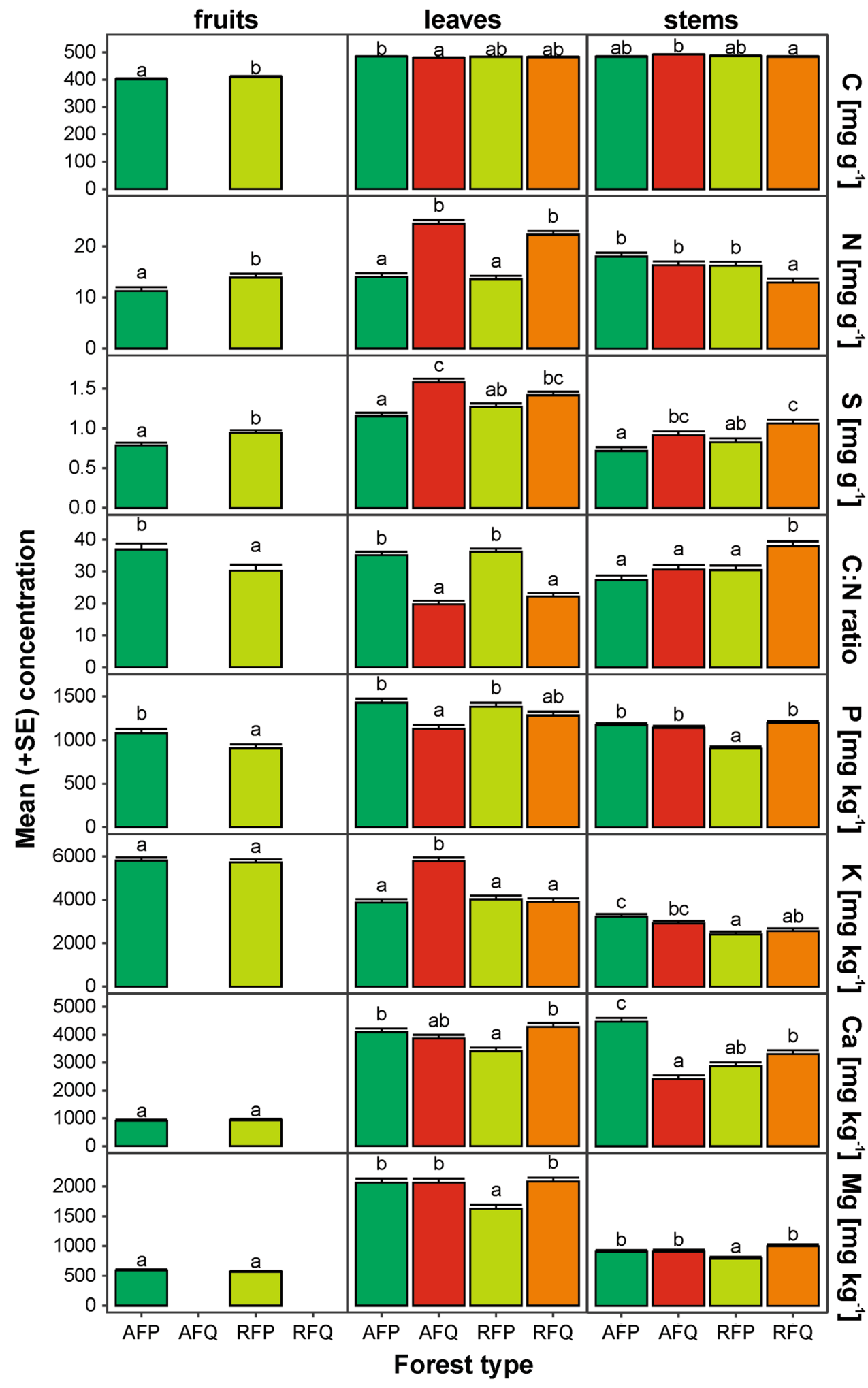

result from lower $\mathrm{N}$ availability, as even fertile forest soils are impoverished in $\mathrm{N}$ in the presence of $Q$. rubra (Nicolini and Topp 2005; Stanek et al. 2020).

Nitrogen, along with phosphorus and sulphur, is present mainly as a constituent of nucleic acids and fatty phospholipids, and all of these elements are accumulated mainly at intensively growing green parts of plants (Haneklaus et al. 2007). The uptake and assimilation of N, S, and $\mathrm{P}$ by plants are strongly interrelated and dependent upon each other (Haneklaus et al. 2007; Sanchez 2007). Sulphur is 


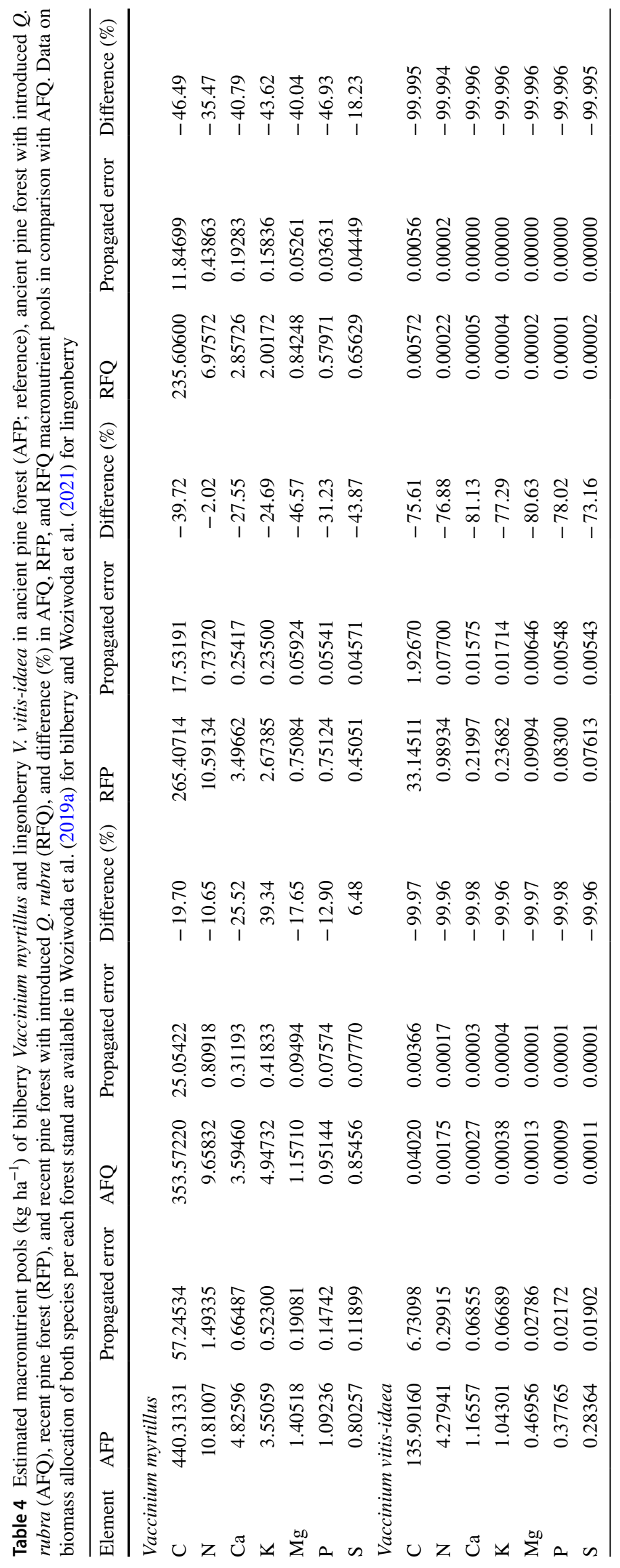


essential for chloroplast growth and function; it is a component of the iron-sulphur complexes of the electron transport chains in photosynthesis (Haneklaus et al. 2007). We found that $Q$. rubra occurrence favoured $\mathrm{S}$ accumulation both in $V$. myrtillus and $V$. vitis-idaea leaves, irrespective of the forest land-use history. The noted high $\mathrm{S}$ concentrations in bilberry and lingonberry fruits were expected as the sulphur-containing amino acids (cysteine and methionine) are present at high levels in seed storage proteins (Tabatabai 1986).

Uptake of the next element-phosphorus-from the soil is positively correlated with $\mathrm{N}$ uptake (Marschner 2012), and high $\mathrm{N}$ and $\mathrm{P}$ availability in soils increases bilberry fruit yield and shoot growth (Nestby et al. 2014a). However, intensive plant growth and fruiting occur only if both elements are available in high amounts or eventually high $\mathrm{N}$ concentration is noted, while even high $\mathrm{P}$ with low $\mathrm{N}$ availability is insufficient for proper plant development (Nestby et al. 2014a). Our study showed that in the presence of $Q$. rubra, V. myrtillus increased $\mathrm{P}$ accumulation in the ancient forest, but decreased it in the recent forest, while V. vitisidaea had decreased $\mathrm{P}$ accumulations in the presence of oak in both recent and ancient forests. The higher P concentration in bilberry plants growing under the closed pine-red oak canopy can be related to more intensive photosynthesis in sites with denser shade, and $\mathrm{P}$ is involved in this process (Van Heerwaarden et al. 2003). A large amount of P is naturally stored within seeds in anticipation of their germination, so more $\mathrm{P}$ noted in bilberries in recent pine forest without than with $Q$. rubra can be explained by limited seed set production in dense shade conditions (Eckerter et al. 2019). However, higher P concentration in fruits collected in an ancient forest with $Q$. rubra than in an ancient pine forest contradicts this theory (unless bilberries from ancient forest contained more seeds; further studies are necessary).

Potassium, unlike other major elements, does not enter into the composition of any of the important plant constituents, but it is involved in numerous metabolic processes, and it usually occurs in all biomass components in substantial amounts (Marschner 2012). Regulating internal plant moisture and being involved in maintaining the water status of the plant by control of the turgor pressure of plant cells and the opening and closing of its stomata, $\mathrm{K}$ is an essential contributor to photosynthesis and respiration (White and Karley 2010). The aforementioned functions explain much higher $\mathrm{K}$ concentration in $V$. myrtillus and $V$. vitis-idaea leaves than stems, as well as its higher concentration in bilberry shoots collected in forests with than without $Q$. rubra (Figs. 3, 5). The latter is interesting, as forest soils occupied by $Q$. rubra are strongly impoverished in K (Nicolini and Topp 2005; Stanek et al. 2020). We hypothesise that the noted soil impoverishment can result not only from more intensive nutrient uptake by $Q$. rubra - as was stated in previous studies-but also due to increased absorption of elements by native understory "survivors" (further study is needed). Thin bilberry leaves contained more than twice as much $\mathrm{K}$ than lingonberry leaves, and much higher $\mathrm{K}$ bioaccumulation in thin than leathery leaves was expected, although both species responded to increased loss of moisture in low light habitats (Leuschner and Ellenberg 2017b) by SLA increase (Paź-Dyderska et al. 2020). The high K concentrations in bilberry and lingonberry berries (Figs. 3,5) resulted in turn from substantial participation of this element in natural processes of fruit ripening and coloration (Upton 2001; Chu et al. 2011).

The high magnesium concentrations in leaves of both species, slightly higher for deciduous bilberry, are explained by the role of $\mathrm{Mg}$ in plants (an important constituent of the chlorophyll molecule and effective activator in numerous enzyme reactions closely related to energy-supplying P-compounds; Marschner 2012). Higher Mg concentration in shoots collected in mixed than pine forests (except lingonberry in the ancient pine forest) can also be explained by more intensive photosynthesis ongoing in plants in light deficiency under a closed canopy. The lower Mg concentration in the whole lingonberry shoots from mixed pine-oak stands than those from pine monocultures can result from the lack of fruits in the former (Woziwoda et al. 2021), as during fruit ripening magnesium is remobilized from vegetative to reproductive tissues (Merhaut 2007). Fruiting limitation in the ancient forest, however, did not change Mg bioaccumulation in lingonberry vegetative organs, while in recent forests $\mathrm{Mg}$ concentrations in leaves and stems were slightly higher in forests with than without $Q$. rubra.

Both $\mathrm{N}$ absorption from the soil to the plant as well as $\mathrm{K}$ transport within are regulated by calcium availability, and the more $\mathrm{N}$ and $\mathrm{K}$, the more $\mathrm{Ca}$ in plant tissues (Marschner 2012). This element is a constituent of cell walls, especially in leaves (Vergutz et al. 2012) and, like $\mathrm{Mg}$, it is involved (among others) in the activation of enzymes necessary for photosynthesis, hence, the naturally high amounts of $\mathrm{Ca}$ found in green biomass components of both species. High amounts of $\mathrm{Ca}$ in long-living plant parts like stems or evergreen (lingonberry) leaves are explained by its tendency to accumulate in plants with plant age (Marschner 2012). However, more than twice as much Ca was found in bilberry than in lingonberry leaves, and the highest $\mathrm{Ca}$ concentration was noted in $V$. myrtillus growing in the recent pine forest with $Q$. rubra. It can be connected to species-specific leaf structure (thinner in bilberry while thicker and leathery in lingonberry) and site-specific rate of water circulation. Calcium ions (immobile in a plant) are transported from the soil to the plant tissues with water by the xylem system. Thinner leaves transpire faster, and in sites with dense shade plant transpiration accelerates (Sjönberg et al., after Atlegrim 1989; Leuschner and Ellenberg 2017b). Faster transpiration means faster water movement within a plant, 
and consequently more intensive Ca uptake (but see: Pilbeam and Morlay 2007). For lingonberry, rapid Ca uptake in high amounts is a very marked characteristic of nutrient absorption (Ingestad 2006). Higher Ca concentration noted in $V$. vitis-idaea stems in ancient pine forests may be in turn linked with the lingonberry strategy for specific biomass accumulation during generative reproduction. In the previous study (Woziwoda et al. 2021), we found that some fruiting shoots (noted exclusively in pine stands without $Q$. rubra) almost completely reduced their leaf biomass. Consequently, the plant transpiration and photosynthesis had to be "taken over" by green stems which resulted in higher $\mathrm{Ca}$ accumulation within.

We are aware that conclusions drawn from our study might be biased by the low replicability (connected with very high labour demand)—each forest type is represented by only one study site, and research plots are probably not independent. This may limit the transferability of the results, and one should be cautious when inferring results and conclusions for other forests. However, despite the lack of replications, assessments of the effects of introduced (invasive) woody species on the biomass of native plants in forests with different histories of land use are scarce, and our study provides novel data that could be used in designing further researches. Lingonberry and bilberry plant biomass components were not separated into the current growing season and older parts of stems and leaves, so results show both long-term and one-season accumulations of nutrients in long-lived stems and evergreen lingonberry leaves, as well as one-season accumulations of nutrients in deciduous bilberry leaves, and fruits of both species.

The second disadvantage of the study is a lack of direct light availability measurements, as light availability is a crucial factor determining plant biomass and nutrient allocation (Karolewski et al. 2013; Czapiewska et al. 2019). However, we used indirect methods, based on functional traits and indicator values of plants (Ellenberg and Leuschner 2010), that are related to light availability (Dzwonko 2001; Jagodziński et al. 2016). As we used vegetation surveys, we assessed community-based responses that neglected intraspecific variability of particular species (Paź-Dyderska et al. 2020), but provided an average response of all species, weighted by their abundance. Moreover, SLA has higher inter- than intraspecific variability (Paź-Dyderska et al. 2020) that allows for conclusions on plant community characteristics. We found a lack of differences among forest types in EIV.L for vascular plants only, but including bryophytes in the analysis revealed higher EIV.L in forest types without $Q$. rubra. Lack of differences accounting for vascular plants results from the low cover of the herbaceous layer, and therefore lower species richness. Bryophytes seem to be more sensitive to the limitation of light availability than vascular plants, similarly as in a multi-comparison study on invasive tree species effects on bryophytes (Dyderski and Jagodziński 2020b). Our results confirmed previous findings of shading by red oak (Niinemets 2010; Jagodziński et al. 2018; Dyderski et al. 2020). However, the ability of Q. rubra to shade the understory is not connected with its functional advantage, but rather with its ability to grow beneath a $P$. sylvestris canopy (Dyderski and Jagodziński 2019). Therefore, the effect of $Q$. rubra can be similar to native oak species. For example, in Western Poland stands with $Q$. rubra transmitted $3.9 \pm 0.5 \%$ of open-sky light, stands with $Q$. petraea transmitted $5.7 \pm 0.6 \%$, while non-invaded $P$. sylvestris stands transmitted $10.2 \pm 1.8 \%$ of full light (Dyderski and Jagodziński 2020a).

However, as Q. rubra is classified in Poland and other European countries as an invasive alien species (Dyderski et al. 2020, and references therein), the effects of its introduction require more attention than of other broadleaved (native) species occurrence. Admittedly $Q$. rubra planting in Polish forests is currently limited, but it still can be used in the transformation of recent Scots pine forests occupying post-agricultural soils to mixed forests. Moreover, mature red oak trees already occur in high numbers in numerous localities in forests (Woziwoda et al. 2014a, b, c), and $Q$. rubra spreads effectively in an uncontrolled way (Woziwoda et al. 2018, 2019b; Chmura 2020; Dyderski and Jagodziński 2020a). Our earlier studies indicated that $V$. myrtillus and $V$. vitis-idaea declined in Q. rubra presence (Woziwoda et al. 2019a, 2021). Decreases in macronutrient pools revealed here for bilberry and lingonberry confirm earlier observations on strong negative effects of this alien tree introduction both on native flora and (consequently) NWFP availability (Woziwoda et al. 2019a, 2021). Differences in nutrient concentrations found for V. myrtillus and V. vitis-idaea in the Scots pine and Scots pine-red oak forests result from changes in abiotic conditions caused by underplanting broadleaved tree species. Decreases in macronutrient pools indicate changes in nutrient accumulations in forest understories which can have far-reaching consequences for nutrient cycling within forest ecosystems. Therefore, we suggest controlling the occurrence of alien $Q$. rubra (as well as other broadleaved species) in pine monocultures and limiting its underplanting in Scots pine monocultures, especially in areas with abundant $V$. myrtillus and $V$. vitis-idaea.

\section{Conclusions}

Forest land-use discontinuity and enrichment of the Scots pine monocultures with $Q$. rubra significantly affected macronutrient bioaccumulation in aboveground shoots of $V$. myrtillus and $V$. vitis-idaea. We found intra- and interspecific (bilberry vs. lingonberry) differences in $\mathrm{N}, \mathrm{S}, \mathrm{P}, \mathrm{K}, \mathrm{Ca}$, and $\mathrm{Mg}$ concentrations and no differences in $\mathrm{C}$ concentrations in bilberry and 
lingonberry leaves, stems, and fruits. Forest land-use continuity favoured the accumulation of nutrients in Vaccinium myrtillus and $V$. vitis-idaea aboveground biomass components, except $\mathrm{P}$ in bilberry. Macronutrient concentrations were also higher in both species in pine forests "enriched" with Q. rubra, both recent and ancient. However, despite the more effective accumulation of elements in $Q$. rubra presence at the species level, at the ecosystem level macronutrient pools of $V$. myrtillus and $V$. vitis-idaea were significantly lower, and the decreases noted resulted from significant changes in bilberry and lingonberry cover and biomass, as a response of both species on forest stand transformation. Therefore, the limitation of Q. rubra occurrence in mesic Scots pine forests in areas with abundant bilberry and lingonberry cover is recommended.

Supplementary Information The online version contains supplementary material available at https://doi.org/10.1007/s10342-021-01414-8.

Acknowledgements We kindly thank Dr. Lee E. Frelich (The University of Minnesota Center for Forest Ecology, USA) for linguistic revision of the manuscript.

Authors' contributions BW conceived the ideas, reviewed the literature, designed field methodology, collected the data, wrote the original draft and edited the manuscript; MKD designed the methodology of statistical analyses and analysed the data, wrote the original draft, and edited the manuscript; AP and JJ designed methodology and carried out chemical analyses; AMJ supervised the formal analyses and revised the final version. All authors read and approved the final manuscript.

Funding This research did not receive any specific grant from funding agencies in the public, commercial, or not-for-profit sectors. However, the research was financially supported by our employers: University of Lodz, Pomeranian University in Słupsk, Warsaw University of Life Sciences and Institute of Dendrology PAS.

Availability of data and materials The datasets used and analysed during the current study are available from the corresponding author on reasonable request.

\section{Declarations}

Competing interests The authors declare that they have no competing interests.

Consent to participate Not applicable.

Consent for publication Not applicable.

Ethics approval Not applicable.

Open Access This article is licensed under a Creative Commons Attribution 4.0 International License, which permits use, sharing, adaptation, distribution and reproduction in any medium or format, as long as you give appropriate credit to the original author(s) and the source, provide a link to the Creative Commons licence, and indicate if changes were made. The images or other third party material in this article are included in the article's Creative Commons licence, unless indicated otherwise in a credit line to the material. If material is not included in the article's Creative Commons licence and your intended use is not permitted by statutory regulation or exceeds the permitted use, you will need to obtain permission directly from the copyright holder. To view a copy of this licence, visit http://creativecommons.org/licenses/by/4.0/.

\section{References}

Atlegrim O (1989) Exclusion of birds from bilberry stands: impact on insect larval density and damage to the bilberry. Oecologia 79:136-139. https://doi.org/10.1007/BF00378251

Barbosa MA, Real R, Muñoz AR, Brown JA (2013) New measures for assessing model equilibrium and prediction mismatch in species distribution models. Divers Distrib 19:1333-1338. https://doi.org/ 10.1111/ddi. 12100

Barker AV, Pilbeam DJ (eds) (2007) Handbook of plant nutrition. CRC Press, Boca Raton

Barker AV, Bryson GM (2007) Nitrogen. In: Barker AV, Pilbeam DJ (eds) Handbook of plant nutrition. CRC Press, Boca Raton, pp 21-50

Bonifacio E, Petrillo M, Petrella F, Tambone F, Celi L (2015) Alien red oak affects soil organic matter cycling and nutrient availability in low-fertility well-developed soils. Plant Soil 395:215-229. https:// doi.org/10.1007/s11104-015-2555-9

Braun-Blanquet J (1964) Pflanzensoziologie. In: Grundzüge der Vegetationskunde, 3rd edn. Springer, Wien, p 865

Bujor O-C, Ginies C, Popa VI, Dufour C (2018) Phenolic compounds and antioxidant activity of lingonberry (Vaccinium vitis-idaea $\mathrm{L}$.) leaf, stem and fruit at different harvest periods. J Food Chem 252:356-365. https://doi.org/10.1016/j.foodchem.2018.01.052

Chmura D (2020) The spread and role of the invasive alien tree Quercus rubra L. in novel forest ecosystems in central Europe. Forests 11(5):586. https://doi.org/10.3390/f11050586

Chu W, Cheung SCM, Lau RAW, Benzie IFF (2011) Bilberry (Vaccinium myrtillus L.). In: Benzie IFF, Wachtel-Galor S (eds) Herbal medicine: biomolecular and clinical aspects, 2nd edn. CRC Press, Boca Raton

Czapiewska N, Dyderski MK, Jagodziński AM (2019) Seasonal dynamics of floodplain forest understory-impacts of degradation, light availability and temperature on biomass and species composition. Forests 10:22. https://doi.org/10.3390/f10010022

Díaz S, Kattge J, Cornelissen JHC, Wright IJ, Lavorel S, Dray S, Reu B, Kleyer M et al (2016) The global spectrum of plant form and function. Nature 529:167-171. https://doi.org/10.1038/natur e16489

Dyderski MK, Jagodziński AM (2019) Similar impacts of alien and native tree species on understory light availability in a temperate forest. Forests 10:951. https://doi.org/10.3390/f10110951

Dyderski MK, Jagodziński AM (2020) Impact of invasive tree species on natural regeneration species composition, diversity, and density. Forests 11(4):456. https://doi.org/10.3390/f11040456

Dyderski MK, Jagodziński AM (2020b) Impacts of alien tree species on the abundance and diversity of terricolous bryophytes. Folia Geobot 55:351-363. https://doi.org/10.1007/s12224-020-09384-2

Dyderski MK, Jagodziński AM (2021) Impacts of invasive trees on alpha and beta diversity of temperate forest understories. Biol Invasions 23:235-252. https://doi.org/10.1007/ s10530-020-02367-6

Dyderski MK, Chmura D, Dylewski Ł, Horodecki P, Jagodziński AM, Pietras M, Robakowski P, Woziwoda B (2020) Biological Flora of the British Isles: Quercus rubra. J Ecol 108:1199-1225. https:// doi.org/10.1111/1365-2745.13375

Dzwonko Z (2001) Assessment of light and soil conditions in ancient and recent woodlands by Ellenberg indicator values. J Appl Ecol 38:942-951. https://doi.org/10.1046/j.1365-2664.2001.00649.x 
Eckerter T, Buse J, Förschler M, Pufal G (2019) Additive positive effects of canopy openness on European bilberry (Vaccinium myrtillus) fruit quantity and quality. For Ecol Manag 433:122-130. https://doi.org/10.1016/j.foreco.2018.10.059

Eeva T, Holmström H, Espín S, Sánchez-Virosta P, Klemola T (2018) Leaves, berries and herbivorous larvae of bilberry Vaccinium myrtillus as sources of metals in food chains at a $\mathrm{Cu}-\mathrm{Ni}$ smelter site. Chemosphere 210:859-866. https://doi.org/10.1016/j.chemo sphere.2018.07.099

Ellenberg H, Leuschner C (2010) Vegetation Mitteleuropas mit den Alpen in ökologischer, dynamischer und historischer Sicht. UTB, Stuttgart

FDB (2018) Forest data bank. https://www.bdl.lasy.gov.pl/portal/en. Accessed 20 June 2018

Fernández-Calvo IC, Obeso JR (2004) Growth, nutrient content, fruit production and herbivory in bilberry Vaccinium myrtillus L. along an altitudinal gradient. Forestry 77:213-223. https://doi.org/10. 1093/forestry/77.3.213

Frelich LE, Machado JL, Reich PB (2003) Fine-scale environmental variation and structure of understory plant communities in two old-growth pine forests. J Ecol 91(2):283-293. https://doi.org/10. 1046/j.1365-2745.2003.00765.x

Grelet G-W, Alexander IJ, Proe MF, Frossard JS, Millard P (2001) Leaf habit influences nitrogen remobilization in Vaccinium species. $\mathrm{J}$ Exp Bot 52(358):993-1002

Haneklaus S, Bloem E, Schnug E, de Kok LJ, Stulen I (2007) Sulphur. In: Barker AV, Pilbeam DJ (eds) Handbook of plant nutrition. CRC Press, Boca Raton, pp 183-238

Havas P, Kubin E (1983) Structure, growth and organic matter content in the vegetation cover of an old spruce forest in Northern Finland. Ann Bot Fenn 20:115-149

Ingestad T (2006) Mineral nutrient requirements of Vaccinium vitisidaea and V. myrtillus. Physiol Plant 29(2):239-246. https://doi. org/10.1111/j.1399-3054.1973.tb03099.x

Jäderlund A, Zackrisson O, Nilsson M-C (1996) Effects of bilberry (Vaccinium myrtillus L.) litter on seed germination and early seedling growth of four boreal tree species. J Chem Ecol 22(5):973986. https://doi.org/10.1007/BF02029948

Jagodziński AM, Dyderski MK, Rawlik K, Kątna B (2016) Seasonal variability of biomass, total leaf area and specific leaf area of forest understory herbs reflects their life strategies. For Ecol Manag 374:71-81. https://doi.org/10.1016/j.foreco.2016.04.050

Jagodziński AM, Dyderski MK, Horodecki P, Rawlik K (2018) Limited dispersal prevents Quercus rubra invasion in a 14-species common garden experiment. Divers Distrib 24:403-414. https://doi. org/10.1111/ddi.12691

Jens R, Uleberg E, Nes A, Krogstad T, Nestby R, Martinussen I (2015) Nutritional composition of bilberries (Vaccinium myrtillus L.) from forest fields in Norway: effects of geographic origin, climate, fertilization and soil properties. J Appl Bot Food Qual 88:274287. https://doi.org/10.5073/JABFQ.2015.088.040

Karolewski P, Giertych MJ, Żmuda M, Jagodziński AM, Oleksyn J (2013) Season and light affect constitutive defenses of understory shrub species against folivorous insects. Acta Oecol 53:19-32

Kilpeläinen H, Salminen O, Härkönen K, Miina J, Kurttila M (2018) Integrating bilberry yields into regional long-term forest scenario analyses. Scan J for Res 33(4):378-386. https://doi.org/10.1080/ 02827581.2017 .1407821

Kleyer M, Bekker RM, Knevel IC, Bakker JP, Thompson K, Sonnenschein M, Poschlod P, Van Groenendael JM et al (2008) The LEDA traitbase: a database of life-history traits of the Northwest European flora. J Ecol 96:1266-1274. https://doi.org/10.1111/j. 1365-2745.2008.01430.x

Kolari P, Pumpanen J, Kulmala L, Ilvesniemi H, Nikinmaa E, Grönholm T, Hari P (2006) Forest floor vegetation plays an important role in photosynthetic production of boreal forests. For Ecol
Manag 221(1-3):241-248. https://doi.org/10.1016/j.foreco.2005. 10.021

Kożuchowski K (2011) Climate of Poland: a new perspective. PWN, Warsaw ((in Polish))

Lahdesmaki P, Pakonen T, Saari E, Laine K, Tasanen L, Havas P (1990) Changes in total nitrogen, protein, amino acids and NH4 + in tissues of bilberry, Vaccinium myrtillus, during the growing season. Holarct Ecol 13:31-38. https://doi.org/10.1111/j.16000587.1990.tb00586.x

Lenth R (2019) emmeans: estimated marginal means, aka least-squares means

Leuschner C, Ellenberg H (2017) Vegetation ecology of central Europe. Ecology of central European forests, vol 1. Springer, Cham

Leuschner C, Ellenberg H (2017) Abiotic conditions, flora, ecosystem functions and recent human influence. In: Leuschner C, Ellenberg H (eds) Ecology of central European forests. Springer, Cham. https://doi.org/10.1007/978-3-319-43042-3_4

Luby JJ, Ballington JR, Darpar AD, Pliszka K, Austin ME (1991) Blueberries and cranberries (Vaccinium). Acta Hortic 290:391456. https://doi.org/10.17660/ActaHortic.1991.290.9

Marschner P (ed) (2012) Marschner's mineral nutrition of higher plants, 3rd edn. Academic Press, New York. https://doi.org/10. 1016/C2009-0-63043-9

Matuszkiewicz JM, Kowalska A, Kozłowska A, Roo-Zielińska E, Solon J (2013) Differences in plant-species composition, richness and community structure in ancient and post-agricultural pine forests in central Poland. For Ecol Manag 310:567-576. https://doi.org/10.1016/j.foreco.2013.08.060

Maubon M, Ponge J-F, Jean A (1995) Dynamics of Vaccinium myrtillus patches in mountain spruce forest. J Veg Sci 6:343-348. https://doi.org/10.2307/3236233

Merhaut DJ (2007) Magnesium. In: Barker AV, Pilbeam DJ (eds) Handbook of plant nutrition. CRC Press, Boca Raton, pp $145-182$

Messier C, Parent S, Bergeron Y (1998) Effects of overstory and understory vegetation on the understory light environment in mixed boreal forests. J Veg Sci 9(4):511-520. https://doi.org/10.2307/ 3237266

Mikulic-Petkovsek M, Schmitzer V, Slatnar A, Stampar F, Veberic R (2015) A comparison of fruit quality parameters of wild bilberry (Vaccinium myrtillus L.) growing at different locations. J Sci Food Agric 95:776-785. https://doi.org/10.1002/jsfa.6897

Nestby R, Percival D, Martinussen I, Opstad N, Rohloff J (2011) The European blueberry (Vaccinium myrtillus) and the potential for cultivation. A review. Eur J Plant Sci Biotechnol 5:5-16

Nestby R, Krogstad T, Joner E, Vohník M (2014a) The effect of NP fertilization on European blueberry (Vaccinium myrtillus L.) development on cultivated land in mid-Norway. J Berry Res 4:147-157. https://doi.org/10.3233/JBR-140077

Nestby R, Martinussen I, Krogstad T, Uleberg E (2014b) Effect of fertilization, tiller cutting and environment on plant growth and yield of European blueberry (Vaccinium myrtillus L.) in Norwegian forest fields. J Berry Res 4:79-95. https://doi.org/10.3233/ JBR-140070

Nicolescu V-N, Vor T, Mason WL, Bastien J-C, Brus R, Henin J-M, Kupka I, Lavnyy V et al (2020) Ecology and management of northern red oak (Quercus rubra L. syn. Q. borealis F. Michx.) in Europe: a review. Forestry 93(4):1-14. https://doi.org/10.1093/ forestry/cpy032

Nicolini F, Topp W (2005) Soil properties in plantations of sessile oak (Quercus petraea) and red oak (Quercus rubra) in reclaimed lignite open-cast mines of the Rhineland. Geoderma 129:65-72. https://doi.org/10.1016/j.geoderma.2004.12.031

Niinemets $\ddot{U}$ (2010) A review of light interception in plant stands from leaf to canopy in different plant functional types and in species 
with varying shade tolerance. Ecol Res 25:693-714. https://doi. org/10.1007/s11284-010-0712-4

Nilsson MC, Wardle WA (2005) Understory vegetation as a forest ecosystem driver: evidence from the northern Swedish boreal forest. Front Ecol Environ 3(8):421-428. https://doi.org/10.1890/15409295(2005)003[0421:UVAAFE]2.0.CO;2

Oksanen J, Blanchet FG, Kindt R, Legendre P, Michin PR, O'Hara RB, Simpson GL, Solymos P, Henry M, Stevens H, Wagner H (2018) "vegan" 2.3.3.: community ecology package

Parzych A (2016) Accumulation and distribution of nutrients in shoots of Vaccinium vitis-idaea L. and Vaccinium myrtillus L. Sylwan 160(1):40-48. https://doi.org/10.26202/sylwan.2015087

Paź-Dyderska S, Dyderski MK, Szwaczka P, Brzezicha M, Bigos K, Jagodziński AM (2020) Leaf traits and aboveground biomass variability of forest understory herbaceous plant species. Ecosystems 23:555-569. https://doi.org/10.1007/s10021-019-00421-6

Peterken GF (1974) A method for assessing woodland flora for conservation using indicator species. Biodivers Conserv 6:239-245. https://doi.org/10.1016/0006-3207(74)90001-9

Pilbeam DJ, Morley PS (2007) Calcium. In: Barker AV, Pilbeam DJ (eds) Handbook of plant nutrition. CRC Press, Boca Raton, pp 121-144

R Core Team (2019) R: a language and environment for statistical computing. R Foundation for Statistical Computing, Vienna

Reich PB, Oleksyn J, Modrzyński J, Mroziński P, Hobbie SE, Eissenstat DM, Chorover J, Chadwick OA, Hale CM, Tjoelker MG (2005) Linking litter calcium, earthworms and soil properties: a common garden test with 14 tree species. Ecol Lett 8:811-818. https://doi.org/10.1111/j.1461-0248.2005.00779.x

Ritchie JC (1955) Biological flora of the British Isles: Vaccinium vitisidaea L. J Ecol 43(2):701-708

Ritchie JC (1956) Biological flora of the British Isles. Vaccinium myrtillus L. J Ecol 44:291-299

Rodriguez A, Kouki J (2015) Emulating natural disturbance in forest management enhances pollination services for dominant Vaccinium shrubs in boreal pine dominated forests. For Ecol Manag 00:1-12. https://doi.org/10.1016/j.foreco.2015.04.029

Sanchez CA (2007) Phosphorus. In: Barker AV, Pilbeam DJ (eds) Handbook of plant nutrition. CRC Press, Boca Raton, pp 51-90

SHS (2003) Soil and Habitat Survey of the Poddębice Forest District. Bureau for Forest Management and Geodesy, Warsaw Department, Production Department in Łódź, [in Polish].

Stanek M, Piechnik Ł, Stefanowicz AM (2020) Invasive red oak (Quercus rubra L.) modifies soil physicochemical properties and forest understory vegetation. For Ecol Manag 472:118253. https:// doi.org/10.1016/j.foreco.2020.118253

Tabatabai MA (ed) (1986) Sulfur in agriculture. Agronomy monographs, vol 27. American Society of Agronomy, Madison. https:// doi.org/10.2134/agronmonogr27

Tegeder M, Masclaux-Daubresse C (2018) Source and sink mechanisms of nitrogen transport and use. New Phytol 217:35-53. https://doi.org/10.1111/nph.14876

Timoshok EE (2000) The ecology of bilberry (Vaccinium myrtillus L.) and cowberry (Vaccinium vitis-idaea L.) in Western Siberia. Russ J Ecol 37(1):8-13. (Translated from Ekologiya 1:11-16). https:// doi.org/10.1007/BF02799719

Turtiainen M, Nuutinen T (2012) Evaluation of information on wild berry and mushroom markets in European countries. Small-scale For 11:131-145. https://doi.org/10.1007/s11842-011-9173-z

Turtiainen M, Miina J, Salo K, Hotanen J-P (2013) Empirical prediction models for the coverage and yields of cowberry in Finland. Silva Fenn 47(3):1005

Uleberg E, Rohloff J, Jaakola L, Trost K, Junttila O, Häggman H, Martinussen I (2012) Effects of temperature and photoperiod on yield and chemical composition of northern and southern clones of bilberry (Vaccinium myrtillus L.). J Agric Food Chem 60:1040610414. https://doi.org/10.1021/jf302924m

Upton R (ed) (2001) Bilberry fruit Vaccinium myrtillus L. standards of analysis, quality control, and therapeutics. American Herbal Pharmacopoeia and Therapeutic Compendium, Santa Cruz

Van Heerwaarden LM, Toet S, Aerts R (2003) Current measures of nutrient resorption efficiency lead to a substantial underestimation of real resorption efficiency: facts and solutions. Oikos 101:664669. https://doi.org/10.1034/j.1600-0706.2003.12351.x

Vergutz L, Manzoni S, Porporato A, Novais RF, Jackson RB (2012) Global resorption efficiencies and concentrations of carbon and nutrients in leaves of terrestrial plants. Ecol Monogr 82:205-220. https://doi.org/10.1890/11-0416.1

White PJ, Karley AJ (2010) Potassium. In: Hell R, Mendel R-R (eds) Cell biology of metals and nutrients. Springer, Berlin, pp 199-224

Woziwoda B, Kopeć D, Witkowski J (2014a) The negative impact of intentionally introduced Quercus rubra L. on a forest community. Acta Soc Bot Pol 83:39-49. https://doi.org/10.5586/asbp.2013. 035

Woziwoda B, Potocki M, Sagan J, Zasada M, Tomusiak R, Wilczyński $S$ (2014) Commercial forestry as a vector of alien tree species: the case of Quercus rubra L. introduction in Poland. Baltic For 20:131-141

Woziwoda B, Krzyżanowska A, Dyderski MK, Jagodziński AM, Stefańska-Krzaczek E (2018) Propagule pressure, presence of roads, and microsite variability influence dispersal of introduced Quercus rubra in temperate Pinus sylvestris forest. For Ecol Manag 428:35-45. https://doi.org/10.1016/j.foreco.2018.06.033

Woziwoda B, Dyderski MK, Jagodziński AM (2019a) Effects of land use change and Quercus rubra introduction on Vaccinium myrtillus performance in Pinus sylvestris forests. For Ecol Manag 440:1-11. https://doi.org/10.1016/j.foreco.2019.03.010

Woziwoda B, Dyderski MK, Kobus S, Parzych A, Jagodziński AM (2019) Natural regeneration and recruitment of native Quercus robur and introduced $Q$. rubra in European oak-pine mixed forests. For Ecol Manag 449:117473. https://doi.org/10.1016/j. foreco.2019.117473

Woziwoda B, Dyderski MK, Jagodziński AM (2021) Forest land use discontinuity and northern red oak Quercus rubra introduction change biomass allocation and life strategy of lingonberry Vaccinium vitis-idaea. For Ecosyst 8:9-15. https://doi.org/10.1186/ s40663-021-00287-y

Woziwoda B, Parzych A, Kopeć D (2014b) Species diversity, biomass accumulation and carbon sequestration in the understorey of postagricultural Scots pine forests. Silva Fenn 48(5):art id 1119

WRB (2015) World Reference Base for Soil Resources 2014, update 2015. International soil classification system for naming soils and creating legends for soil maps. World Soil Resources Reports No. 106. FAO, Rome

Wright IJ, Reich PB, Westoby M, Ackerly DD, Baruch Z, Bongers F, Cavender-Bares J, Chapin T et al (2004) The worldwide leaf economics spectrum. Nature 428:821-827. https://doi.org/10.1038/ nature 02403

Zvereva EL, Kozlov MV (2005) Growth and reproduction of dwarf shrubs, Vaccinium myrtillus and $V$. vitis-idaea, in a severely polluted area. Basic Appl Ecol 6:261-274. https://doi.org/10.1016/j. baae.2004.11.003

Publisher's Note Springer Nature remains neutral with regard to jurisdictional claims in published maps and institutional affiliations. 